\title{
Plasmids of phenanthrene and dibenzothiophene-degrading bacteria isolated from produced water samples of oil production operations
}

\author{
C. Chuma OKORO ${ }^{1 *}$, O. Olukayode AMUND ${ }^{2}$ and Ron ELIORA ${ }^{3}$ \\ ${ }^{1}$ Department of Biological Sciences and Biotechnology. Caleb University, Lagos Nigeria. \\ ${ }^{2}$ Department of Botany and Microbiology. University of Lagos, Nigeria. \\ ${ }^{3}$ Department of Bioscience and Biotechnology, University of Tel-Aviv Israel. \\ *Corresponding author, E-mail: chuma2k2001@yahoo.com Tel: 08033072754, 01-7430285.
}

\begin{abstract}
Some bacterial isolates from produced water that showed extensive degradation of Polycyclic aromatic hydrocarbons $(\mathrm{PAH})$ in produced water were screened for the presence of catabolic plasmids targeted for the degradation of phenanthrene and dibenzothiophene (DBT) to determine whether the genes responsible for the degradation of these substrates reside in either plasmid or chromosomal DNA. When grown on phenanthrene, Acinetobacter lwoffi, Enterobacter sp. and Pseudomonas sp. harbored some plasmids with molecular weights less than $23.1 \mathrm{kbp}$ except Pseudomonas $s p$ that harbored plasmids with molecular weight higher than $48.5 \mathrm{kbp}$. When Corynebacterium sp., Vibrio sp. and Pseudomonas aeruginosa were grown on dibenzothiophene (DBT), Plasmids with molecular weights higher than $48.5 \mathrm{kbp}$ were found in these organisms. Upon further investigation and curing with acridine orange, the resident plasmids were lost in phenanthrene and DBTdegrading isolates but all the organisms retained their abilities to grow on these compounds. This result indicates that the genes for the degradation of phenanthrene and DBT in these organisms probably reside in the Chromosomal DNA as opposed to the Plasmid DNA.

(C) 2009 International Formulae Group. All rights reserved.
\end{abstract}

Keywords: Plasmids, phenanthrene, dibenzothiophene, produced water, bacteria.

\section{INTRODUCTION}

Phenanthrene is a low molecular weight Polycyclic Aromatic Hydrocarbons (PAH). PAHs are compounds containing Carbon and Hydrogen with the carbon atom arranged in a series of adjoining six membered benzene rings and they are present in produced water, crude oil and tars. PAH's are known to be recalcitrant and are not easily degradable. They are also considered hazardous because of their potential trophic biomagnification and acute toxicity (Davville and Wilham, 1984). Dibenzothiophene (DBT) is a representative group of heterocyclic compounds which include thiophene, benzothiophene and benzonaphthothiophene (Monticello et al., 1985). These thiophene derivatives are known to be common in crude oil and rock extracts (Constanti et al., 1993). Dibenzothiophene and substituted derivatives represent important components of the sulfur containing heterocyclic organic compounds found in crude petroleum. Microbial transformation of DBT is therefore of interest in the potential desulphurization of oil, since high levels of thiophene and other Scontaining compounds lead to the generation of Sox which is toxic to the environment.

Produced water is the formation water that comes along during the production of oil and gas, and there is no doubt that most of petroleum hydrocarbon components found in crude oil will also be present in the produced water. Plasmids are small circular extra- 
chromosomal DNA molecules that replicate independently in an organism. Some of the microbial catabolic pathways responsible for the degradation of hydrocarbons have been extensively characterized and are found to be located on large catabolic plasmids found in most Pseudomonas species (Sayler et al., 1990). Monticello et al. (1985) demonstrated that degradation of DBT by Pseudomonas species was plasmid mediated. They isolated three soils Pseudomonas species which oxidized DBT to its characteristics water soluble sulfur containing products, and two of their isolates harbored a 55 megadalton plasmid. Other researchers like Kosheleva et al. (2000), Anokhina et al. (2004) and Somnath et al. (2007) have equally demonstrated that biodegradation of phenanthrene is plasmid mediated. It is generally believed that catabolic pathways which encode numerous aromatic hydrocarbon degradation pathways are frequently located on plasmids and in the case of DBT and PAH, it is believed that the genes that are responsible for their degradation can be located on the plasmids. On the contrary, Etamadifer et al. (2006) have demonstrated the degradation of dibenzothiophene by Trichosporon sp., which was not plasmid mediated. In this study, some bacterial cultures that showed remarkable degradation of PAHs in produced water were grown on phenanthrene and DBT to verify whether the genes that are responsible for their degradation are located on the plasmids or chromosomal DNA.

\section{MATERIALS AND METHODS}

Enumeration of hydrocarbon utilizing bacteria

Hydrocarbon utilizing bacterial counts in produced water samples were obtained by using the mineral salts medium of Mills et al. (1978). The composition of the medium is as follows (in $\mathrm{g} / \mathrm{l}$ ): $\mathrm{NaCl}$ (10), $\mathrm{MgSO}_{4} .7 \mathrm{H}_{2} 0$ (0.42), $\mathrm{KCl}(0.29), \mathrm{KH}_{2} \mathrm{PO}_{4}$ (0.83), $\mathrm{Na}_{2} \mathrm{HP} \mathrm{O}_{4}$ (1.25), $\mathrm{NaNO}_{3}$ (0.42), Agar bacteriological (15), and $\mathrm{pH}$ adjusted to 7.2. The medium was autoclaved at $1.1 \mathrm{~kg} / \mathrm{cm}^{2}$ for $15 \mathrm{~min}$. The inoculated mineral agar plates were then inverted over sterile membrane filters moistened with crude oil (Escravos light) and held in the lid of the Petri dishes. The dishes were wrapped round with a masking tape so as to increase the vapor pressure within the Petri dishes while the plates were incubated at $29{ }^{\circ} \mathrm{C}$ for 6 days, after which the growth of hydrocarbon degrading bacteria were observed and counted.

Biodegradation of phenanthrene and dibenzothiophene (DBT) by pure bacterial cultures

A weighed quantity of phenanthrene or dibenzothiophene $(2 \mathrm{~g})$ as the case may be was solubilized in $20 \mathrm{ml}$ of normal hexane. Pure bacterial cultures isolated from produced water were incubated in a sterile $250 \mathrm{ml}$ glass bottle containing $50 \mathrm{ml}$ of mineral salts medium as described by Mills et al. (1978) with phenanthrene as the sole carbon source. The composition of the medium is as follows (in g/l): $\mathrm{NaCl}(10), \mathrm{MgSO}_{4} .7 \mathrm{H}_{2} \mathrm{O}(0.42), \mathrm{KCl}$ (0.29), $\quad \mathrm{KH}_{2} \mathrm{PO}_{4}$ (0.83), $\quad \mathrm{Na}_{2} \mathrm{HP} \quad \mathrm{O}_{4} \quad(1.25)$, $\mathrm{NaNO}_{3}(0.42)$, phenanthrene (0.2) and $50 \mathrm{ml}$ of Sulfur deficient mineral salts medium as described by Hou and Laskin (1976) with DBT as the sole carbon source, the composition of the medium is as follows (in $\mathrm{g} / \mathrm{l}): \mathrm{Na}_{2} \mathrm{HPO}_{4} .12 \mathrm{H}_{2} \mathrm{O}$ (9.5), $\mathrm{KH}_{2} \mathrm{PO}_{4}$ (1.4), $\mathrm{MgCl}_{2} \cdot 6 \mathrm{H}_{2} \mathrm{O}$ (0.2), $\mathrm{NH}_{4} \mathrm{Cl}$ (5), $\mathrm{FeCl}_{2}$ (0.1), DBT (0.2) and n-parrafin $(2 \mathrm{ml})$. The bacterial cultures were grown as starter cultures in Nutrient Broth for $18 \mathrm{hrs}$ and introduced into the mineral salts medium in 5 $\mathrm{ml}$ aliquots. The initial $\mathrm{pH}$ was 7.2 and the incubation period was for 3 weeks at $29{ }^{\circ} \mathrm{C}$ in a stationery condition. Organisms that grew on phenanthrene and DBT were isolated and screened for plasmids.

\section{Detection and isolation of plasmids}

The method adopted for plasmid isolation and detection was as described by Kado and Liu (1981). Bacterial cultures were grown in L-broth (Luria Bertani Broth) for 18 $\mathrm{hr}$ at $30{ }^{\circ} \mathrm{C}$ to give an optical density of about 0.80 (at $600 \mathrm{~nm}$ ). The bacterial cells (about 3 $\mathrm{ml}$ ) were pelleted by centrifugation at 5,700 rpm for $7 \mathrm{~min}$ at $4{ }^{\circ} \mathrm{C}$ and suspended in $1 \mathrm{ml} \mathrm{E}$ buffer (40 Mm Tris and $2 \mathrm{Mm}$ EDTA ). Two milliliters of lysis solution made up of Sodium dodecyl sulphate (SDS) and Tris (1:1 v/v) were added and the solution was heated to 50$60{ }^{\circ} \mathrm{C}$ for $20 \mathrm{~min}$ in a water bath and 2 volumes of Phenol Chloroform solution (1:1 $\mathrm{v} / \mathrm{v})$ were added. The solution was emulsified by shaking briefly and the emulsion was 
broken by centrifugation $(6000 \mathrm{rpm}, 15 \mathrm{~min}$ and $4{ }^{\circ} \mathrm{C}$ in Sorvall SS34 rotor). In order to avoid the precipitate at the interface, the upper aqueous phase was transferred to the screw cap tube using a polythene Pasteur pipette. To minimize shearing of large plasmids, samples were withdrawn and transferred with Drummond 50-microliter micropipette for gell electrophoresis.

\section{Agarose gel electrophoresis}

Agarose Gel Electrophoresis (0.7 Seakem ME agarose) was used in plasmid detection. To resolve high molecular weight plasmids, a low salt buffer system composed of $40 \mathrm{mM}$ Tris-acetate and $2 \mathrm{mM}$ Sodium EDTA was used. The Tris was adjusted to $\mathrm{pH}$ 7.9 with glacial acetic acid (E. buffer). Agarose was melted briefly (3-5 min) in $\mathrm{E}$ buffer in a microwave oven and mixed well before pouring. The electrophoresis was performed in a horizontal apparatus as described by Kado and Liu (1981). Photographs were taken of gels that were positioned over a shortwave UV light source and a Polaroid film exposed through a Titten 15 orange filter was used.

\section{Curing with acridine orange}

Curing with acridine orange was performed according to the method of Miller (1972). Nutrient broth $(2 \mathrm{ml})$ in screw cap test tubes was supplemented with acridine orange (Sigma) at $25 \mu \mathrm{l} / \mathrm{ml}$ increments from $25-125$ $\mu 1 / \mathrm{ml}$. Inoculation was carried out with about $10^{6}$ cells of plasmid bearing phenanthrene and DBT degrading bacteria. The tubes were incubated with shaking for $48 \mathrm{hrs}$ at $30{ }^{\circ} \mathrm{C}$. The cultures in tubes with the highest concentration of acridine orange that allowed growth were serially diluted and plated on nutrient agar to give 20-60 colonies per plate. Master and replica plating of the colonies were carried out on nutrient agar and minimal salts - phenanthrene and DBT agar, as the case may be, to identify colonies that have lost phenanthrene or DBT degrading ability. The putative cured strains were later examined for plasmids as described above.

\section{RESULTS}

Screening of some bacterial isolates for the presence of plasmids
The following hydrocarbon utilizing bacterial isolates from produced water were screened for plasmids. Bacillus sp., Pseudomonas sp., Acinetobacter lwoffii, Achromobacter sp., Enterobacter sp., Pseudomonas mallei, Pseudomonas pseudomallei, Corynebacterium sp., Vibrio sp., Pseudomonas aeruginosa, Alcaligenes sp. and Serratia marcescens. They were grown individually on phenanthrene and dibenzothiophene (DBT) in pure cultures and later screened for plasmids. Some of the bacterial cultures showed presence of plasmids after growth on phenanthrene and DBT as shown in Figures 1 and 2. The cultures that showed presence of plasmids were subjected to further investigation.

\section{Cured bacterial strains}

The plasmid bearing bacterial strains that were cured with acridine orange are Pseudomonas sp., Enterobacter sp., Vibrio sp. and Corynebacterium sp. All the strains retained their full ability to grow on phenanthrene and DBT after acridine orange treatment and this prompted further screening for plasmids of three putative cured strains of Pseudomonas sp., but no plasmids were found as can be seen in figure 3 .

\section{DISCUSSION}

Catabolic pathways for numerous aromatic hydrocarbon degradation are usually located on the plasmids; this suggests that the genes that are responsible for degradation of hydrocarbons can be located in the Plasmid DNA (Jae-Chang and Sang-Jong, 2001). Traditionally, most genes that are responsible for the degradation of hydrocarbons are expected to be located on the Chromosomal DNA, plasmids are just extra chromosomal elements that may carry catabolic genes. It has been shown that most of the bacteria that carried out extensive petroleum hydrocarbon degradation in produced water do not possess plasmids (Okoro, 1999). In the present study some plasmids were found in some bacteria species that utilizes phenanthrene and DBT as their sole carbon and energy source and some attempts were made to find out whether the genes that specified their degradation were located on those plasmids. After growth on phenanthrene for instance, a plasmid with a 


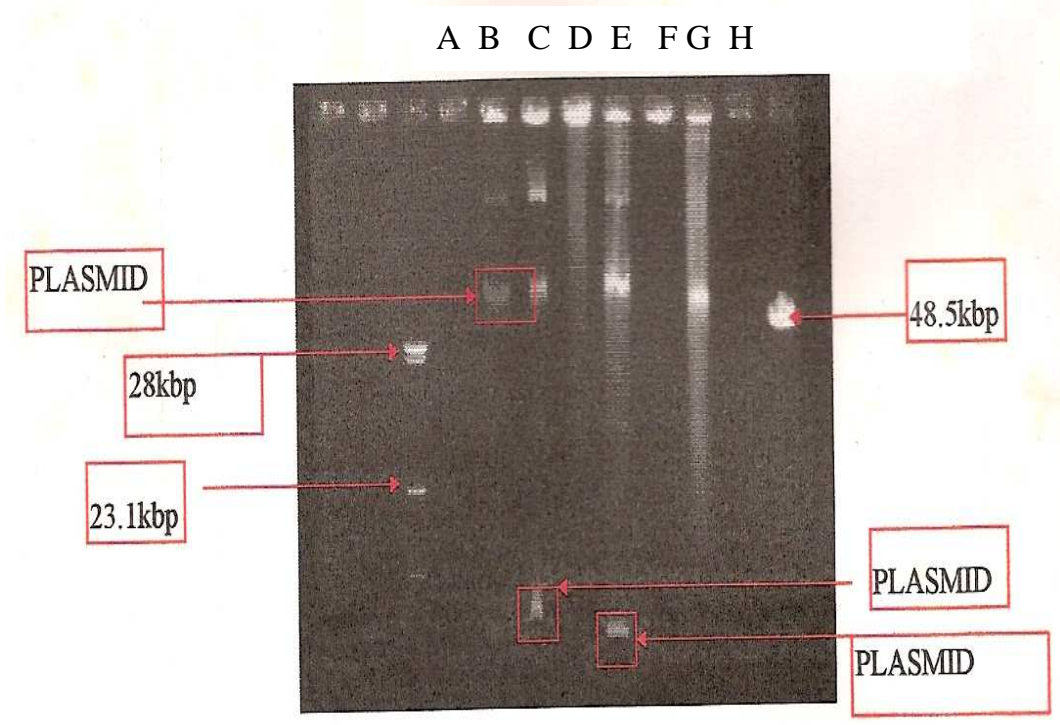

Figure 1: Plasmids of some bacterial strains grown on phenanthrene. LANE: BACTERIAL CUlTURE, A- Bacillus sp. B- Pseudomonas sp. C- Acinetobacter lwoffii, D- Achromobacter sp. EEnterobacter $\mathrm{sp}$. F- Pseudomonas pseudomallei, G- Pseudomonas mallei 28 kbp, 23.1 kbp, $48.5 \mathrm{kbp}$ (Standard Markers In Kilo Base Pairs).

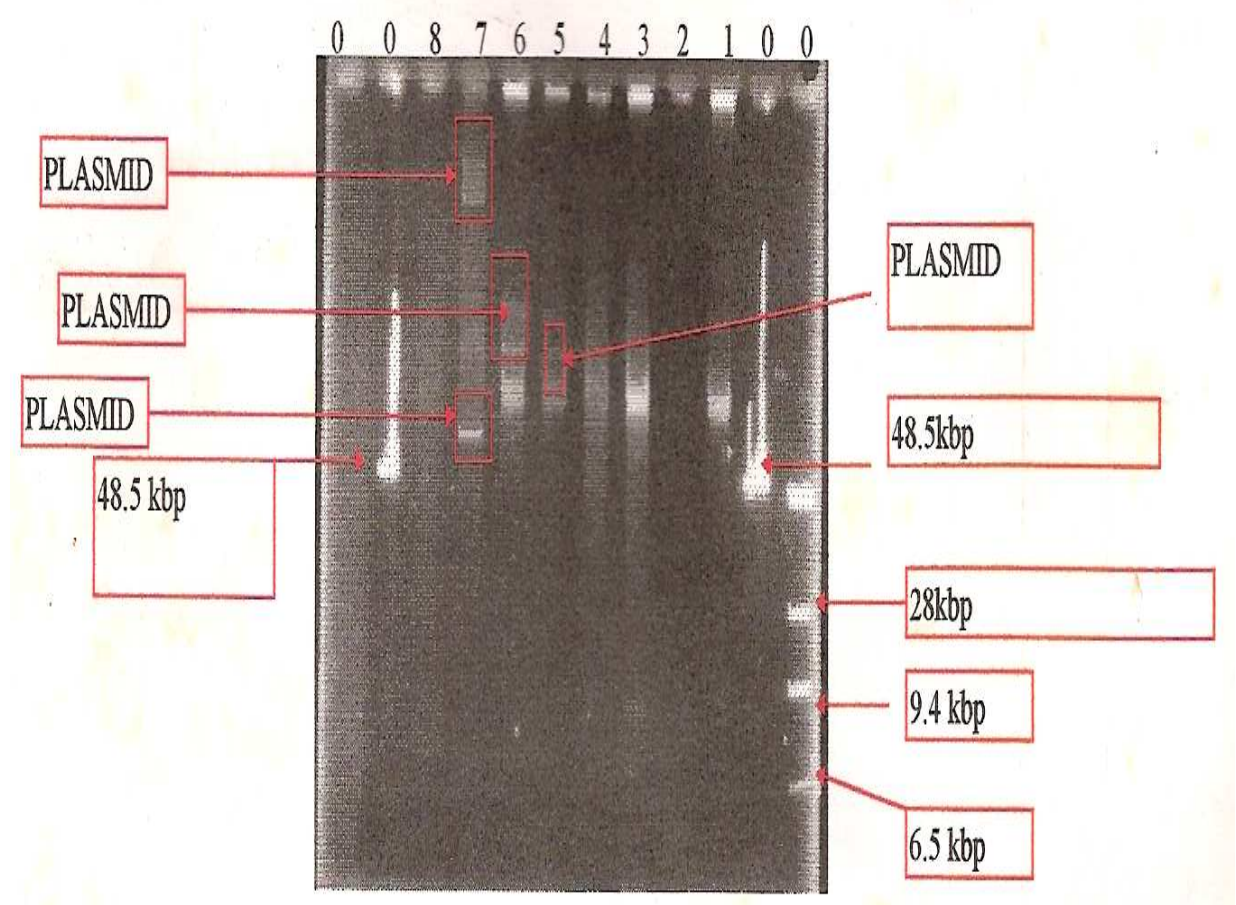

Figure 2: Plasmids of some bacterial strains grown on dibenzothiophene (DBT). LANE: BACTERIAL CULTURE, 8- Pseudomonas pseudomallei 7- Corynebacterium sp. 6-Vibrio sp. 5- Pseudomonas aeruginosa 4- Alcaligenes sp. 3- Serratia marcescens 2- Bacillus Sp. 1- Pseudomonas mallei, 0- Standard Markers in Kilo Base Pairs (kbp) 


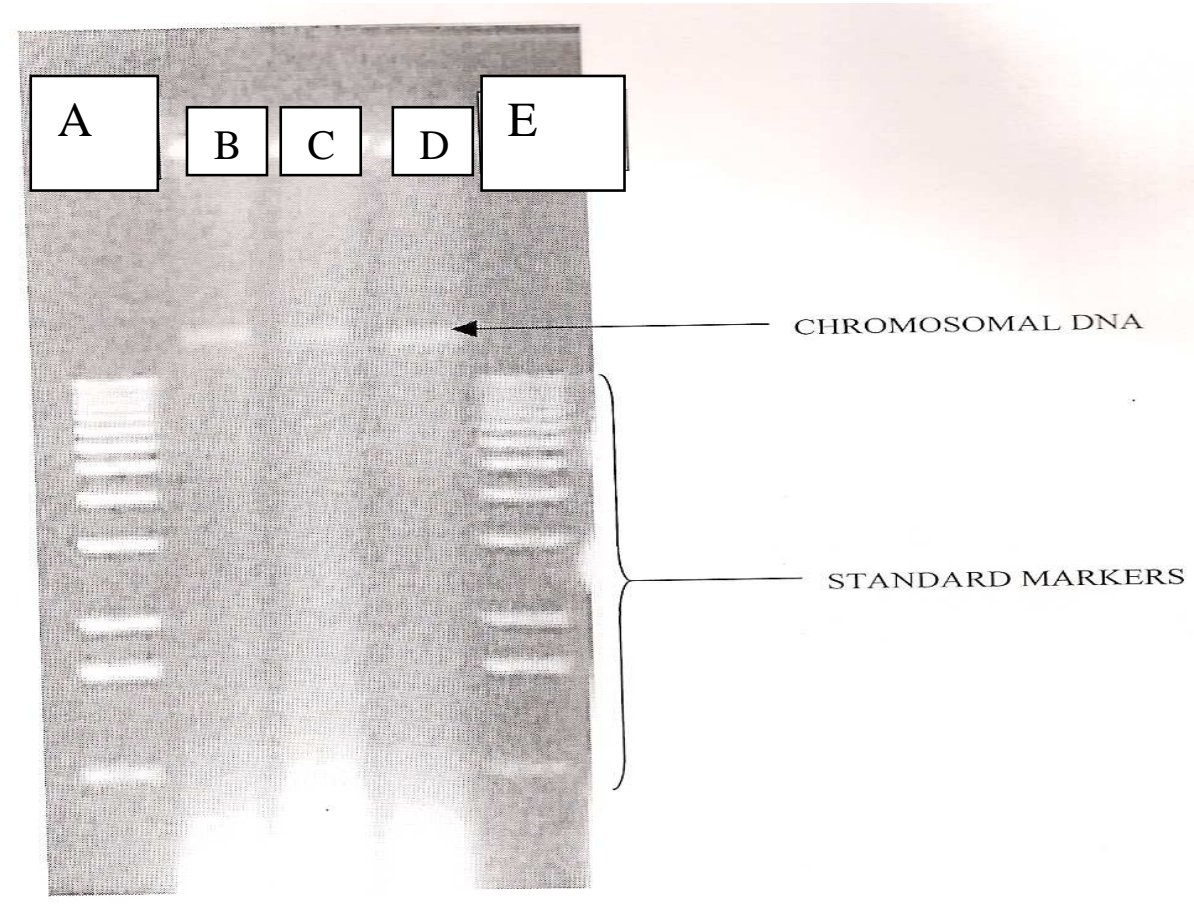

Figure 3: Chromosomal DNA of three putative cured strains of Pseudomonas sp. with acridine orange. LANE A\&E $=$ Standard Markers, LANES B, C and $\mathrm{D}=$ Three putative cured strains of Pseudomonas sp.

molecular weight slightly higher than 48.5 kbp was located in Pseudomonas sp. Acinetobacter lwoffi and Enterobacter sp. also had plasmids with molecular weights lower than $23.1 \mathrm{kbp}$ after growth on phenanthrene. Similarly, after growth on DBT, Corynebacterium sp., Vibrio Sp. and Pseudomonas aeruginosa had plasmids with individual molecular weights each higher than $48.5 \mathrm{kbp}$, but all these plasmids were lost after curing with acridine orange as shown by agarose gel electrophoresis; however they still retained their ability to grow and utilize phenanthrene and DBT as sole carbon and energy sources. This is an indication that the genes that are responsible for the degradation of these compounds are not present on the plasmid DNA.

Some researchers have on the contrary located the genes for degradation of these compounds in the plasmid DNA. For instance the genes for the degradation of phenenthrene by Pseudomonas putida strains were located on the plasmids (Kosheleva et al., 2000).
Anokhina et al. (2004) also identified some plasmids that degraded phenanthrene in Pseudomonas sp., while Somnath et al. (2007) located some phenanthrene degrading plasmids in Staphylococcus sp. Gokhan and Serap (2005) isolated a $26 \mathrm{kbp}$ plasmid from a strain of Pseudomonas sp. that was found to be responsible for the degradation of phenanthrene. In the case of DBT, Monticello et al. (1985) and Mormile and Atlas (1988) have also located DBT degrading genes in the plasmid bearing Pseudomonas species. On the contrary, Etamadifar et al. (2006) have demonstrated that DPT degradation by Torulopsis sp. is not plasmid mediated. The present study have shown that not all plasmids that are seen in organisms utilizing certain compounds as their sole energy and carbon source are involved in the degradation of such compounds, as the plasmids may be involved in some other genetic functions. From the available data, it can be concluded that the plasmids found in the produced water bacterial isolates after growth on 
phenanthrene and DBT are not responsible for the degradation of these compounds. The genes that are responsible for the degradation probably reside in the chromosomal DNA since these organisms retain their normal growth characteristics on these compounds after losing their plasmids.

\section{ACKNOWLEDGEMENTS}

I wish to thank UNESCO for providing funds for this research and the Department of Biosciences and Biotechnology, University of Tel-Aviv Israel for providing laboratory facilities and materials and most especially I am grateful to Prof. Eugene Rosenberg and Prof Ron Eliora for their support and encouragement.

\section{REFERENCES}

Anokhina TO, Kochetkov VV, Zelenkova NF, Balakshina VV, Boronin AM. 2004. Biodegradation of phenanthrene by Pseudomonas bacteria bearing rhizospheric plasmids in model plant microbial associations. Appl. Biochm and Microbiol., 40(6): 568-575.

Constanti M, Bordons A, Giralt J. 1993. Degradation of dibenzothiophene by Pseudomonas putida. Lett. Appl. Microbiol., 18: 107-111.

Davville RG, Wilham JL. 1984. The effect of naphthalene and oxygen consumption and haemoglobin concentration of Chiroromus attenuates and the cycle of Tanytarus dissimilis. Environ. Toxicol. Chem., 3: 135-141.

Etemadifer Z, Emtiazi G, Peimanfer S. 2006. Removal of dibenzothiophene, biphenyl and phenol from waste by trichosporon sp. Sci. Res. and Ess., 1(3): 072-076.

Georg LS. 2008. Plasmids: Current Research and Future Trends. Caister Academic Press (Publ.); 264p.

Gokhan C, Serap K. 2005. Isolation and characterization of phenanthrene degrading bacteria from a petroleum refinery soil. Annals Microbiol., 55(4): 255-259.

Hou CT, Laskin AI. 1976. Microbial conversion of dibenzothiophene. Dev. Ind. Microbiol., 17: 351-362.

Jae-Chang C, Sang-jong K. 2001. Detection of megaplasmid from polycyclic aromatic hydrocarbon degrading Sphingomonas $s p$. strain KS14. J. Mol. Microbiol. Biotechnol., 3(4): 503-506.

Kado CI, Liu ST. 1981. Rapid procedure for detection and isolation of large and small plasmids. J. Bacteriol., 145(3): 13631373.

Kosheleva A, Baleshova NV, Izmalkova TY, Filonov AE, Sokolor SL, Slepenkin AV, Boron AM. 2000. Degradation of phenanthrene by mutant naphthalenedegrading Pseudomonas putida. Microbiol., 69(6): 663-669.

Miller JH. 1972. Experiments in Molecular Genetics. Cold Spring Harbour: New York; 11724.

Mills AL, Brenil C, Colwell RR. 1978. Enumeration of petroleum degrading marine and estuarine microorganisms by most probable number method. Can. J. Microbiol., 24: 552-557.

Monticello DJ, Bakker D, Finnerty WR. 1985. Plasmid degradation of dibenzothiophene by Pseudomonas species. Appl. Environ. Microbiol., 49: 756-760.

Mormile MR, Atlas RM. 1988. Mineralisation of dibenzothiophene biodegradation products, 3-hydroxy-formyl benzothiophene and dibenzothiophene sulphone. Appl. Environ. Microbiol., 54(12): 31833184.

Okoro CC. 1999. Microbial degradation of hydrocarbons in produced water from crude oil production operations in Escravos Tank Farm. PhD. Thesis. University of Lagos, Nigeria, 269p.

Sayler GS, Hopper SW, Layton HC, Henryking JM. 1990. Catabolic plasmids of environmental and ecological significance. Microbial. Ecol., 19: 1-20.

Somnath M, Subhankar C, Tapan KD. 2007. A novel degradation pathway in the assimilation of phenanthrene by Staphylococcus Sp. strain $\mathrm{PN} / \mathrm{Y}$ via metacleavage of 2-hydroxy-1-naphthoic acid. Microbiol., 153: 2104-2115.

Yoshikazu I, Takashi O, Hiroshi O, Yoshimitsu H, Masahuki S. 1994. Selective Desulfurisation of Dibenzothiophene by Rhodococcus erythropolis D-1. Appl. Environ. Microbiol., 60(1): 223-226. 